\title{
Responses by general practitioners in Avon to proposals for general practice in the white paper Working for Patients
}

\author{
Michael Whitfield, Neil Wood, Fiona Wright
}

\begin{abstract}
Objective-To determine the views of Avon's general practitioners about the general practice proposals within the government's white paper Working for Patients.

Design-Postal questionnaire survey.

Setting - A county in south west England.

Subjects-All general practitioner principals ( $\mathrm{n}=$ 537) under contract with Avon Family Practitioner Committee.

Measurements and main results -492 doctors $(92 \%)$ responded to the survey. More than three quarters of the respondents were opposed to the government's proposals on budgets for specific surgical procedures, prescribing, and diagnostic tests; and between $63 \%$ and $93 \%$ felt negative about advantages that might accrue from the proposals. Over three quarters of general practitioners were in favour of family practitioner committees monitoring work load, prescribing, and referrals. General practitioners in large, potentially budget holding practices held similar views to doctors in smaller practices.

Conclusions-Avon's general practitioners substantially reject most of the government's proposals about general practice in the white paper Working for Patients.
\end{abstract}

\section{Introduction}

In January 1989 the government issued the white paper Working for Patients. ${ }^{1}$ The stated reasons for the review of the NHS include the need to raise the standards of care and secure best value for money, the rising cost of providing care, the wide variation in cost of the care provided, and the desire to extend patient choice. The government believes that these will be best achieved by delegating responsibility to where health care is delivered to the patient.

The proposals for general practice centre on the government's belief that money should flow with the patient from the practice. For the first time since the start of the NHS this concept introduces the need for a general practitioner to know accurately the cost consequences of most clinical decisions. To encourage the doctor to take on this new managerial role the government proposes to allow eligible general practitioners to plough back savings into their practices.

The proposals will necessitate the development of practice budgets for outpatient services, certain specified surgical procedures, diagnostic tests, and prescribing. They will also require the development of obligatory systems for medical audit. Other proposals include increasing capitation fees paid for patients registered with the doctor while reducing basic practice allowances, easing the regulations for changing doctors, encouraging doctors to provide information about their practices, and reducing the professional representation on family practitioner committees.
Despite the Prime Minister's assertions' that patients' needs will always be paramount and that greater satisfaction and rewards will be available for those working in the NHS, the medical profession has reacted strongly against the proposals. ${ }^{23}$ These major changes, introduced with proposals for developing a competitive market for the hospital services, have been criticised by the General Medical Services Committee (GMSC), who have asked local medical committees to ascertain the views of local doctors. ${ }^{4}$ To do this the Avon local medical committee circulated a questionnaire to all general practitioners in Avon asking for their views on the proposals in the white paper. Information about the general practitioners' current use of computers, and prescription, analysis, and cost (PACT) prescribing information was also requested to determine their present interest in monitoring their work.

\section{Subjects and methods}

Questionnaires were sent to all 537 general practitioners in contract with Avon Family Practitioner Committee. The area comprises three large towns, Bristol, Bath, and Weston super Mare, and surrounding rural areas. The questionnaire comprised a series of questions to determine doctors' views on the content and consequences of the proposals in the white paper and the possible time scale for their implementation. There were possible responses to each of yes, no, and (when applicable) don't know (see table 1). The doctors' age group, sex, health district, and the number of partners in each practice was also identified. Information about respondent's and practice's use of computers, high level (PACT) prescribing information, and where the doctor had gained information about the white paper was also requested. Questionnaires were sent out in March 1989: a reminder was sent to those general practitioners not responding within three weeks. Non-parametric analyses were performed to test hypotheses of average differences in the obtained responses among subgroups of doctors.

\section{Results}

Questionnaires were received from 492 (91.6\%) doctors. Table I shows the responses to the questions about the proposals, and table II shows views on the likely effects of the white paper if implemented as proposed. Most general practitioners in Avon expressed opposition to all but two of the proposals.

Most respondents were in favour of general practitioners cooperating with the family practitioner committee in monitoring workload, prescribing, referrals, etc $(78.8 \%$ in favour) and retiring at 65 $(60.1 \%$ in favour). Doctors aged 45 and younger were more likely than older colleagues to agree that general 
TABLE I-Overall responses from 492 general practitioners to questionnaire on government proposals for NHS. Results are numbers (percentages)

\begin{tabular}{|c|c|c|c|}
\hline Questions asked & Yes & No & Don't know \\
\hline \multicolumn{4}{|l|}{$\begin{array}{l}\text { In principle, do you feel that a practice should have a fixed } \\
\text { budget for: }\end{array}$} \\
\hline $\begin{array}{l}\text { Referrals for specified operations? } \\
\text { Prescribing? } \\
\text { Diagnostic procedures? }\end{array}$ & $\begin{array}{l}32(6 \cdot 6) \\
98(20 \cdot 1) \\
44(9 \cdot 1)\end{array}$ & $\begin{array}{l}441(90 \cdot 4) \\
368(75 \cdot 4) \\
429(88 \cdot 3)\end{array}$ & $\begin{array}{ll}15 & (3 \cdot 1) \\
22 & (4 \cdot 5) \\
13 & (2 \cdot 7)\end{array}$ \\
\hline $\begin{array}{l}\text { Do you agree that capitation fees should form a greater part of } \\
\text { general practitioners' income? }\end{array}$ & $61(12 \cdot 5)$ & $408(83 \cdot 8)$ & $18(3 \cdot 7)$ \\
\hline $\begin{array}{l}\text { Do you agree that basic practice allowance should form a } \\
\text { reduced part of remuneration? }\end{array}$ & $25(5 \cdot 1)$ & $435(89 \cdot 1)$ & $28(5 \cdot 7)$ \\
\hline $\begin{array}{l}\text { Do you agree that general practitioners should be made to } \\
\text { retire at } 65 \text { ? }\end{array}$ & $297(60 \cdot 1)$ & $175(35 \cdot 8)$ & $17(3.5)$ \\
\hline $\begin{array}{l}\text { Do you feel that general practitioners should cooperate with } \\
\text { family practitioner committees in monitoring work load, } \\
\text { prescribing, referrals etc? }\end{array}$ & $383(78 \cdot 8)$ & $77(15 \cdot 8)$ & $26(5 \cdot 3)$ \\
\hline $\begin{array}{l}\text { Do you believe that general practitioners should be able to use } \\
\text { budgetary savings to increase their personal income? }\end{array}$ & $44(9 \cdot 0)$ & $422(86 \cdot 5)$ & $22(4 \cdot 5)$ \\
\hline $\begin{array}{l}\text { Do you accept that it is reasonable for family practitioner } \\
\text { committees to impose financial penalties on general } \\
\text { practitioners who persistently overspend their indicative } \\
\text { prescribing budgets? }\end{array}$ & $130(26 \cdot 6)$ & $288(58.9)$ & $71(14 \cdot 5)$ \\
\hline $\begin{array}{l}\text { Do you agree that family practitioner committees should be } \\
\text { reduced to } 15 \text { members, of which only one will be a general } \\
\text { practitioner? }\end{array}$ & $22(4 \cdot 5)$ & $439(89.8)$ & $28(5 \cdot 7)$ \\
\hline $\begin{array}{l}\text { Do you believe that the regional health authority will be able } \\
\text { to allocate appropriate budgets for large practices by April } \\
1991 \text { ? }\end{array}$ & $40(8 \cdot 1)$ & $332(67 \cdot 6)$ & $119(24 \cdot 2)$ \\
\hline $\begin{array}{l}\text { Do you believe the family practitioner committees will be able } \\
\text { to accurately monitor overspending in referrals by April } \\
1991 \text { ? }\end{array}$ & $30(6$ & $357(72.9)$ & $103(21 \cdot 0)$ \\
\hline Have you asked for level 2 or 3 PACT prescribing information? & $233(47 \cdot 8)$ & $241(49 \cdot 4)$ & $14(2.9)$ \\
\hline
\end{tabular}

A small number of respondents did not answer all of the questions.

TABLE II-Overall beliefs about consequences of white paper among 492 general practitioners. Results are numbers (percentages)

\begin{tabular}{lccr}
\hline White paper provisions will result in: & Yes & No & Don't know \\
\hline A more cost effective NHS & $98(20 \cdot 0)$ & $325(66 \cdot 5)$ & $66(13 \cdot 5)$ \\
A more efficient NHS & $40(8 \cdot 2)$ & $391(80 \cdot 0)$ & $58(11 \cdot 9)$ \\
Shorter waiting lists & $47(9 \cdot 6)$ & $346(70 \cdot 6)$ & $97(19 \cdot 8)$ \\
Greater equality of patient care & $17(3 \cdot 5)$ & $443(90 \cdot 6)$ & $29(5 \cdot 9)$ \\
Increased personal income for general practitioners & $34(7 \cdot 0)$ & $313(64 \cdot 1)$ & $141(28 \cdot 9)$ \\
Improved doctor/patient relationships & $13(2 \cdot 6)$ & $456(92 \cdot 9)$ & $22(4 \cdot 5)$ \\
A greater proportion of cost of NHS being used within the & $49(10 \cdot 1)$ & $306(63 \cdot 4)$ & $128(26 \cdot 5)$ \\
$\quad$ community & $49(10 \cdot 1)$ & & \\
\hline
\end{tabular}

A small number of respondents did not answer all of the questions.

practitioners should retire at $65\left(\chi^{2}=12 \cdot 01, \mathrm{df}=2\right.$, $\mathrm{p}<0.005)$ and that general practitioners should cooperate with the family practitioner committee in medical audit $\left(\chi^{2}=21 \cdot 5, \mathrm{df}=2, \mathrm{p}<0.001\right)$. Nearly half of the doctors stated that they had asked for level 2 or 3 of the PACT prescribing information. Once again there was a significant average age related difference in the responses: $52 \cdot 2 \%$ of the doctors aged 45 and under and $39 \cdot 9 \%$ aged over 45 had done so $\left(\chi^{2}=7 \cdot 80, \mathrm{df}=2\right.$, $\mathrm{p}<0.025)$. Of the respondents, $27 \%$ believed that it was reasonable for family practitioner committees to impose financial penalties on those doctors who persistently overspend their indicative prescribing budgets. This percentage rose to $33.5 \%$ in general practitioners aged 45 and over $\left(\chi^{2}=7.62, \mathrm{df}=2\right.$, $\mathrm{p}<0.025)$. Few believed that health authorities will be able to allocate appropriate budgets $(8 \cdot 2 \%)$ or monitor over spending in referrals $(6 \cdot 1 \%)$ by April 1991, though about a quarter of the doctors were uncertain. The replies received seemed to be based on informed opinion concerning the content of the white paper as more than three quarters of the sample said they had read the white paper itself (table III).

TABLE III-Overall responses from 492 general practitioners about where they gained information about white paper

\begin{tabular}{lc}
\hline Information from & $\begin{array}{c}\text { No }(\%) \text { of } \\
\text { general practitioners }\end{array}$ \\
\hline Original source & $381(77 \cdot 4)$ \\
Media including medical newspapers & $365(72 \cdot 4)$ \\
Medical journals & $334(67 \cdot 9)$ \\
Talking with colleagues & $330(67 \cdot 1)$ \\
Other & $89(18 \cdot 1)$ \\
\hline
\end{tabular}

Crucial to the implementation of proposals is the degree of computerisation within general practice. Of the general practitioners responding, $59 \%$ said that their practice did not have a computer, although $46 \%$ of this group said that they were actively investigating the use of a computer within their practice.

The proposed qualifying point for larger practices to handle their own budgets is 11000 patients. The average list size in Avon is about 2000 patients, so virtually all practices with six or more partners are likely to qualify for budgets. There are 18 such practices in Avon, which compares with the 23 practices said to be eligible for budgets (Avon Family Practitioner Committee administrator, personal communication). To determine whether the views of partners within large practices differed significantly from those in smaller practices we compared the answers given by doctors within both types of practices. Overall, 105 replies were from doctors working in practices of six or more partners. There were two significant differences between these two subsamples. Of those in potentially budget holding practices, $11 \%$ believed that the provisions of the white paper, if implemented in full, would result in increased personal income for the general practitioner compared with $6 \%$ in smaller practices $\left(\chi^{2} 7 \cdot 31, \mathrm{df}=2, \mathrm{p}<0.05\right)$. The other finding indicated that $58 \%$ of doctors in larger practices had asked for level 2 or 3 PACT prescribing information compared with $44 \%$ of their colleagues in smaller practices $\left(\chi^{2} 7 \cdot 04, \mathrm{df}=2, \mathrm{p}<0.05\right)$.

\section{Discussion}

Any regional study of general practitioners' views can be criticised on the grounds that the general practitioners within that region are not a representative sample. The general practitioners within Avon can be compared with others by examining their performance as monitored by the family practitioner committee. Avon Family Practitioner Committee has good performance indicators for vaccination and immunisation rates, cervical cytology screening, and provision of contraceptive care compared with other large nonmetropolitan family practitioner committees. ${ }^{\text {s }}$ The practices within Avon may therefore be expected to conform to the government's preferred practices rather more than those performing less well. In fact, almost $79 \%$ of the doctors were in favour of the proposals for medical audit, which implies that the Secretary of State for Health is not correct to suggest the adverse reaction to the white paper is because "the BMA... have never been in favour of any change of any kind."

The white paper is described by the Prime Minister as "the most far-reaching reform of the NHS in its forty year history." We have found that more than three quarters of general practitioners object to the idea of fixed budgets for specified surgical operations, prescribing, and diagnostic procedures and to increasing the proportion of a general practitioner's income that comes from capitation fees and reducing the importance of basic practice allowances. Of the general practitioners, $87 \%$ opposed the idea of using budgetary savings to increase their personal income, which may result from being able to plough back budgetary savings into a practice. It seems unlikely therefore that the general practitioners' reactions to the proposals are because they are "feeling nervously for their wallets." The concerns reflected in most replies were principally that the proposals were not likely to improve doctorpatient relationships, provide greater equality of patient care or shorter waiting lists, or result in a more cost effective NHS (see table II).

The applications of information technology are steadily increasing within the NHS. About $40 \%$ of the general practitioners had at least one computer within 
their practice. Most general practitioners did not believe that monitoring of referrals or allocation of appropriate budgets would be possible by April 1991 . This scepticism is shared by others. The public accounts committee said, "Resource Management Initiative may not be operational for a number of years." "The editors of a health service computing journal said, "Can Mr Clarke seriously expect information technology to be the engine room of NHS change when its performance to date is so demonstrably patchy?" and the Secretary of State for Health is quoted as saying that "We haven't a clue" when asked about management costs. ${ }^{8}$ One widely held view is, "Why does it need so many changes to bring about a free flow of information, rational use of resources, and a better deal for patients and staff? Wouldn't it be cheaper to modify what is already there?"10

The government's approach seems to centre on the hope that general practitioners, as a collection of small businesses, will be encouraged to develop entrepreneurial skills and that these will overcome the conservatism and reservations about the possible reduction in the quality of the doctor-patient relationship and of patient care. Our study indicates that doctors within large practices hold a similar range of views on these issues to those in smaller practices. At present, they are not persuaded that the white paper proposals for general practice are workable, are good for patients, or will improve the cost effectiveness of the NHS. Even in larger practices, the few who believe that they are likely to improve their personal incomes are unlikely to be able to persuade their colleagues to succumb to the governments' financial incentives.

We thank the general practitioners for their prompt and willing responses to our questionnaire and members of our department for their considerable help in distributing the questionnaire, processing the data, and constructive criticism.

1 Secretaries of State for Health, Wales, Northern Ireland, and Scotland. Working for Patients. London: HMSO, 1989. (Cmnd 555.)

2 Anonymous. Duncan Nichol writes a letter [Editorial]. BrMed f 1989;298:778.

3 Beecham L. GPs criticise government's plans for NHS. Br Med f 1989;298: 528-32.

4 General Medical Services Committee. Report to a special conference of loca. medical committees on 27 April 1989. London: British Medical Association, 1989.

Avon Family Practitioner Committee. Profile and strategy statement 1986/71991-2. Bristol: Avon FPC, 1987 6 Hall C. A boyish Dr Clarke suggests the pill. Independent $1989 \mathrm{Feb} 2: 7$ (col 7 ). BrMed f 1989;298:704.
Br

8 John Warden. No clues from Clarke on NHS review. Br Med $\mathcal{J}$ 1989;298: 777-8.

9 Anonymous. Business as usual [Editorial]. British Joumal of Health Care Computing 1989;6:1.

10 Anonymous. Curtains up on the NHS review [Editorial]. Lancet 1989;1:248-9.

\section{BOOKS RECEIVED} Acquired immune deficiency syn-
drome

Counselling in HIV Infection and AIDS Ed J Green, A McCreaner. (Pp xi+ 331; \{12.95 paperback.) Oxford: $331 ; \mathfrak{1} 12.95$ paperback.) Oxford:
Blackwell Scientific, 1989. ISBN 0632-01924-7.

Pathology and Pathophysiology of AIDS and HIV-Related Diseases. Ed S Harawi, C J O'Hara. (Pp xv+ 512; figs: £75.) London: Chapman and Hall, 1989. ISBN 0-412-29140-1

WHO AIDS Series. 3. "Guidelines for Nursing Management of People InfecNursing Management of People Infected with Human Immunodeficiency
Virus (HIV)." World Health OrganisVirus (HIV)." World Health Organis-
ation. (Pp iv +42; Sw frs 9 paperback.) ation. (Pp iv +42 ; Sw frs 9 paperback.)
Geneva: World Health Organisation 1988. ISBN 92-4-121003-6.

\section{Addiction}

Practical Guides for General Practice. 5 "Alcohol Problems." P Anderson, $P$ Wallace, $H$ Jones. (Pp $x+86$ figs; 55.95 paperback.) Oxford: Oxford University Press, 1988 ISBN 0-19-261752-4.

\section{Alternative medicine}

Herbal Medicine. R F Weiss. Translated by A R Meuss. (Pp x+362; figs; lated by A R Meuss. (Pp x +362 ; figs;
$£ 29.50$ paperback, or $£ 31.50$ post paid $£ 29.50$ paperback, or $£ 31.50$ post paid
UK, $£ 34.65$ airmail overseas, from UK, $\{34.65$ airmail overseas, from publisher.) Gothenburg: Arcanum,
1988. Distributed by Beaconsfield 1988. Distributed by Beaconsfield Road, Beaconsfield Bucks HP9 IPL. ISBN 0-906584-19-1.

Studies in the History of Alternative Medicine. Ed R Cooter. ( $\mathrm{Pp} \mathrm{xx}+180$ figs; £29.50.) London: Macmillan, 1989, in association with St Antony's College, Oxford. ISBN 0-333-46213-0.

Bone

Quantitative Methods in Bone Densitometry. A L Huddleston. (Pp xii + 217 figs; $\{53.50$.) Boston: Kluwer, 1988 ISBN 0-89838-362-5.

\section{Cardiology}

Comprehensive Electrocardiology: Theory and Practice in Health and Macfarlane, T D Veitch Lawrie. (Ppxliv+1785; figs; £275.) New York: Pergamon, 1988. ISBN 0-08 035568-4.
Ophthalmology

$A B C$ of Eyes. Articles published in the British Medical fournal. A R Elkington, P T Khaw. (Pp 55; figs and colour plates; $£ 9.95$, overseas $£ 12.50$ (\$21) paperback, including postage, airmail paperback, including postage, airmail
overseas. BMA members $\$ 8.95$, overseas 111.50 ( $\$ 19)$, including postage.) seas $\mathfrak{1 1} .50(\$ 19)$, including postage.) London: British Medical

Manual of Glaucoma: Diagnosis and Management. T Krupin. (Pp vii +257; figs; $£ 32.50$ paperback.) New York: Churchill Livingstone, 1988. ISBN 0-443-08510-2.

\section{Paediatrics}

Paediatric Audiology 0-5 Years. Ed B McCormick. (Pp v+354; figs; $£ 36$ hardback, \&16 paperback.) London: Taylor and Francis, 1988. ISBN h/b 0-85066-462-4, p/b 0-85066-463-2.

\section{Pathology}

Diagnostic Cytopathology. A Test and Colour Atlas. C Grubb. (Pp viii +214; colour plates; 229.50 paperback.) Edinburgh: Churchill Livingstone, 1988. ISBN 0-443-03050-2. Pathogenesis of Leprosy and Related
Diseases. D S Ridley. ( $\mathrm{Pp}$ xii +250 ; Diseases. D S Ridley. (Pp xi1+250;
figs; 160 .) London: Wright, 1988. figs; 160.$)$ London: Wright, 1988.
Distributed by Butterworth. ISBN Distributed by

Pathology Annual. Part 2, Vol 23. Ed $P$ P Rosen, R E Fechner. (Pp x + 406; figs; £52.95.) Connecticut: Appleton and Lange, 1988. Distributed by Prentice-Hall International. ISBN 0-8385-7789-X.

\section{Perinatal care}

Contemporary Issues in Fetal and Neonatal Medicine. No 4. "Bronchopulmonary Dysplasia." Ed T A Merritt, W H Northway Jr, B R Boynton. General series editors N N Finer, M L Chiswick. (Pp xv+452; figs; \&45.) Boston: Blackwell Scientific, 1988. ISBN 0-86542-047-5.

\section{Pharmacology}

Drugs and the Pharmaceutical Sciences. Vol 35. "Transdermal Drug Delivery: Developmental Issues and Research
Initiatives." Ed J Hadgraft, R H Guy. Series editor J Swarbrick. (Pp x +324 figs; \$119.50.) New York: Dekker, 1989. ISBN 0-8247-7991-6.

Manual of Drug Interactions for Anesthesiology. R A Mueller, D B A Lundberg. (Pp xlvii+336; 119.95 paperback.) New York: Churchill paperback.) New York: Churchill 08572-2.

Multinational Drug Companies: Issues in Drug Discovery and Development. B Spilker. (Pp xxvi+606; figs; $\$ 86.50$.) New York: Raven Press, 1989. ISBN 0-88167-463-X.

Pharmacology from A to Z. J Carpenter. (Pp x +117; $£ 4.95$ paperback.) Manchester: Manchester University Press, 1988. ISBN 0-7190-2692-X.

\section{Pharmacology - clinical}

Clinical Pharmacology '88/'89. Ed B G Katzung. (Pp xii +467 ; £9.95 paperback. London: Prentice-Hall International, 1988. ISBN 0-8385-1301-8. The Quinolones. Ed V T Andriole. (Pp xii +262; figs; £37.) London: Academic Press, 1988. Distributed by Harcourt Brace Jovanovich. ISBN 0-12-059515-X.

\section{Psychiatry}

Advances in Biological Psychiatry. Vol 17. "Selective 5-HT Reuptake Inhibitors: Novel or Commonplace Agents?" Ed M Gastpar, J S Wakelin. Agents?" Ed M Gastpar, J S Wakelin.
Series editors J Mendlewicz, H M van Series editors J Mendlewicz, H M van Praag. (Pp iii+107; figs; $\mathbf{1 4 4 . 6 0}$.)
Basel: Karger, 1988. Distributed by Basel: Karger, 1988. Distributed by
John Wiley and Sons. ISBN 3-8055John W.

The Scope of Epidemiological Psychiatry: Essays in Honour of Michael Shepherd. Ed P Williams, G Wilkinson, K Rawnsley. (Pp xiv +536 ; figs 0-415-01814-5.

\section{Psychology}

Sexuality and Chronic Illness. $A$ Comprehensive Approach. L $\mathbf{R}$ Schover, S B Jensen. (Pp ix +357 \$35.) New York: Guilford Press, \$35.) New York: Guilfor
1988. ISBN 0-89862-715-X.

\section{Radiology}

Essential Chest Radiology. J B
Cookson, D B L Finlay. (Pp vi+151; figs; $\$ 12.50$ paperback.) Oxford Heinemann Medical, 1988. ISBN 0-433-00047-3.

Key Anatomy for Radiology. S Westacott, J R W Hall. (Pp viii +227 figs; $£ 17.50$ paperback.) Oxford: Heinemann Medical, 1988. ISBN 0-433-00043-0.

\section{Rehabilitation}

Therapy in Practice. "Rehabilitation of the Older Patient: a Handbook for th Multidisciplinary Team." Ed A Squires. Series editor J Campling. ( $P p$ $\mathrm{x}+279 ; £ 11.95$ paperback.) London: Croom Helm, 1988. ISBN 0-7099. 5423-9.

\section{Social services}

A Need for Care? Elderly Applicants for Local Authority Homes. J Neill, I Sinclair, P Gorbach, J Williams. (Pp xii+243; £25.) Aldershot:

\section{Surgery}

Clinical Thinking in Surgery. E Sterns. (Pp xii +642 ; figs; $£ 24.50$ paperback.) London: Prentice-Hall International, 1988. ISBN 0-83851302-6.

Dermatologic Surgery: Principles and Practice. Ed R K Roenigk, H H Roenigk Jr. (Pp xx+1433; figs; $\$ 180$.) New York: Dekker, 1989. ISBN 0-8247-7926-6.

A Very Short Textbook of Surgery. P Ryan. (Pp v+86; \$A15 paperback.) Canberra: Dennis and Ryan, 1988. ISBN 0-7316-3522-1.

\section{Third world}

Planning India's Health-Update 1988. K S Sanjivi (Pp viii +289; Rs7 paperback.) 1988. M A Chidambara Institute of Community Health, Voluntary Health Services, Adyar, TTTI Post, Madras 600 113, India.

\section{Ultrasonics}

Hysterosalpingography and Pelvic Ultrasound: Imaging in Infertility and Gynecology. I C Yoder. (Pp xvi+204; figs; £52.50.) Boston: Little Brown,

1988. Distributed by Churchill Livingstone. ISBN 0-316-96881-1.

\section{Vascular surgery}

Vascular Birthmarks: Hemangiomas and Malformations. J B Mulliken, A E Young. (Pp xii + 483; figs and colour 